\title{
The research on the sifting from processing of East Donbass refuse heap for manufacturing wall ceramics goods
}

\author{
Khungianos Yavruyan ${ }^{1, *}$, Evgeny Gaishun ${ }^{1}$, Yuliya Teryokhina ${ }^{1}$, and Vladimir Kotlyar $^{1}$ \\ ${ }^{1}$ Don state technical university, 344022, Gagarina, 1, Rostov-on-Don, Russia
}

\begin{abstract}
The results of the research into sifting of eastern Donbass gob pile processing as raw material for manufacturing wall ceramics, that is popular industrial raw material of the region, are highlighted in the report. It is stated that the main sifting components are siltstones, clay slates, claystone, and sandstones. The main minerals of the sifting are feldspar, crystalline silica, mica, and hydromica. The haracteristic of sifting handling ability for which the most suitable is the way of goods compression molding at elevated pressure and reduced humidity is given. It is stated that the main technology factors are grain composition of raw material mass, its humidity, compression pressure and firing temperature. Variation of technology factors' data makes it possible to get different kinds of products (course, lining, arch brick) with a wide range of features. Methods of evaluation of quality merit rating and the way this rating affects properties of final product are offered. There is high economical perspective of sifting implementation for production of wall ceramics.
\end{abstract}

Currently, active processing of the refuse heap is taking place in the coal-mining districts of Rostov region (Eastern Donbass). It is mainly being done for the purpose of coal extraction which lately has become economically reasonable. Some secondary elements are being extracted while processing apart from coal. These elements are classified by grain size composition. Fractions $0-0,5$ and $0-2 \mathrm{~mm}$, containing coal at the rate of $15-50 \%$, are used as fuel adding during the production of ceramic bricks and as low energy [1-3]. The material with the size ranging from $4-6 \mathrm{~mm}$ to $80-90 \mathrm{~mm}$ is broken up and is implemented as broken stone in building. Fraction $2-6 \mathrm{~mm}$, that hardly contains any coal and is called sifting, is the list popular for some reasons. General sifting supplies in Rostov region make up several millions of tons and continue to grow.

All Eastern Donbass gob piles are divided by the prevailing kind of composing rocks to three groups:

- made up by claystone and clay slate;

- made up by siltstones and sandstones;

- of mixed composition, made up by claystone, clay slate, siltstones and sandstones.

* Corresponding author: Khungianos@mail.ru 
The last-mentioned type is the most popular. Moreover, geological structure of Eastern Donbass coal mass has a characteristic property of layered structure and alternation of claystone, clay slate, siltstone and sandstone beds that also affects gob pile structure $[2,4]$. While processing, rock mass of the muck stack undergoes breaking up by Blake sledgers and cone crushers, sifting, enrichment by different ways etc., which results in the weakest soft rocks, particularly clay slates and claystone, appearing in the sifting (Figure 1,2).

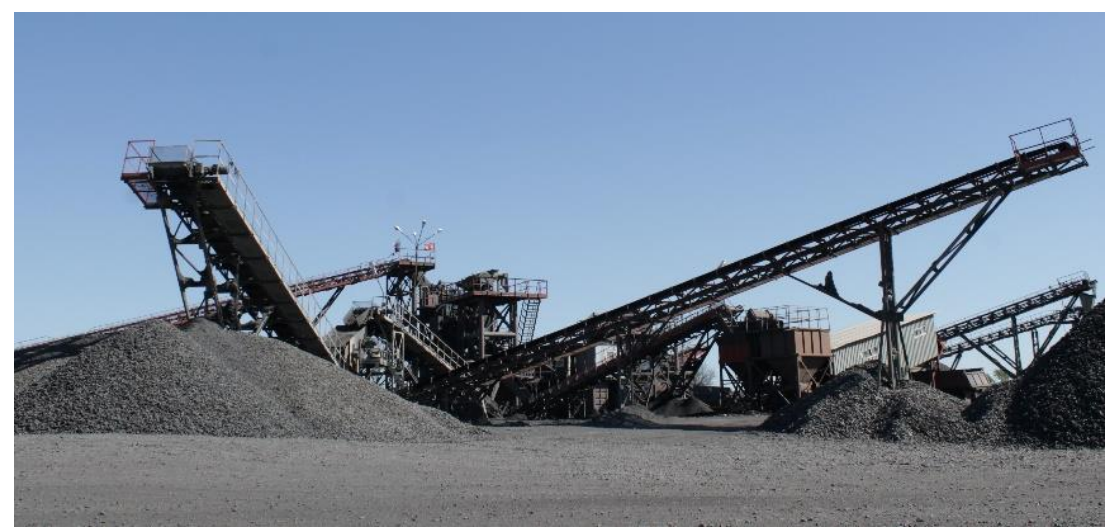

Fig. 1. Refuse heap processing

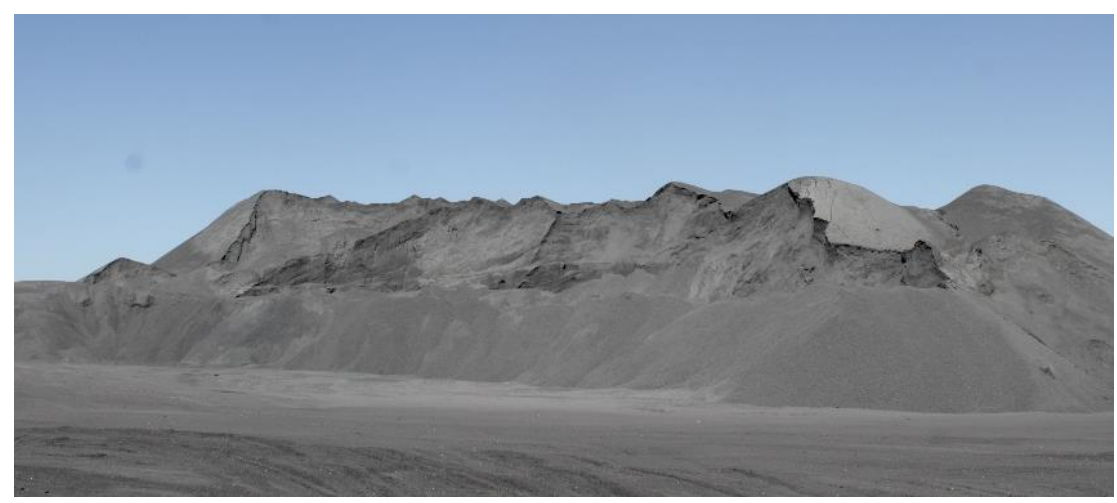

Fig. 2. Refuse heap siftings in storage

Having studied several dozens of siftings of refuse heap breaking up by composing rocks' kind and number, we have divided them into four groups:

- I group - siftings where the content of clay stone and clay slate is more than $80 \%$;

- II группа - siftings where the content of clay stone and clay slate varies between 50 $80 \%$ and the content of siltstones and sandstones does from 20 to $50 \%$;

- III group - siftings where the content of clay stone and clay slate varies between 20$50 \%$ and the content of siltstones and sandstones does from 50 to $80 \%$;

- IV группа - siftings where the content of siltstones and sandstones is more than $80 \%$.

Average grain composition of the siftings is presented in table 1. It is characterized by rather high gradation factor and due to this rate it can be referred to the group of largegrained sand with small amount of fraction $0,16-0,315 \mathrm{~mm}$ and less than $0,16 \mathrm{~mm}$. 
Table 1. Average grain composition of the siftings

\begin{tabular}{|c|c|c|c|c|c|c|c|}
\hline \multirow{2}{*}{$\begin{array}{l}\text { Name of the } \\
\text { remains }\end{array}$} & \multicolumn{5}{|c|}{ Remains, $\%$ in mass, in the sieves } & \multirow{2}{*}{$\begin{array}{l}\text { Pouring through } \\
\text { the net } \\
\text { No. 016, \% in } \\
\text { mass }\end{array}$} & \multirow{2}{*}{$\begin{array}{l}\text { Gradation } \\
\text { factor }\end{array}$} \\
\hline & 2,5 & 1,25 & 0,63 & 0,315 & 0,16 & & \\
\hline partial & 28,3 & 31,8 & 14,7 & 11,5 & 7,3 & 6,4 & \multirow[t]{2}{*}{3,43} \\
\hline total & 28,3 & 60,1 & 74,8 & 86,3 & 93,6 & - & \\
\hline
\end{tabular}

The siftings don't differ significantly in chemical composition from average clay raw material and is characterized by the content of $\mathrm{AI}_{2} \mathrm{O}_{3}$ от 16 до $22 \%$ and the content of calcined potash more than $4 \%$. This is due to some characteristics of the mineral composition. Average chemical composition of the siftings is presented in Table 2.

Table 2. Average chemical composition of the siftings, $\%$ in mass

\begin{tabular}{|c|c|c|c|l|l|l|l|l|l|c|}
\hline $\mathrm{LOI}$ & $\mathrm{SiO}_{2}$ & $\mathrm{AI}_{2} \mathrm{O}_{3}$ & $\mathrm{Fe}_{2} \mathrm{O}_{3}$ & $\mathrm{CaO}$ & $\mathrm{MgO}$ & $\mathrm{SO}_{3}$ & $\mathrm{~K}_{2} \mathrm{O}$ & $\mathrm{Na}_{2} \mathrm{O}$ & $\mathrm{P}_{2} \mathrm{O}_{5}$ & $\mathrm{TiO}_{2}$ \\
\hline $\begin{array}{c}10,2 \\
7\end{array}$ & $52-60$ & $16-22$ & $4-7$ & $1-4$ & $1-4$ & $0,2-0,6$ & $3-5$ & $\begin{array}{c}0,2- \\
1,0\end{array}$ & $\begin{array}{c}0,1- \\
0,3\end{array}$ & $, 4-1,0$ \\
\hline
\end{tabular}

The mineral composition of the siftings is represented by several minerals as it can be seen from the X-ray analysis. As an example, X-ray pattern of the siftings from one of the II group technogenic deposits of is given in figure 3. Hydromica (illite) is present in all samples. This can be seen from the peaks 4,48, 5,06 и 10,16 $\AA$. As a rule, it is the main mineral. However, judging by the activity of the peaks, it has a varying rate of its structural perfection and is present in variable numbers in samples from different deposits. Hydromica (illite) is a typical clay mineral which refers to a hydromica group. It has the same structural pattern of 2:1 type as montmorillonite but, as opposed to it, aluminum ions, which isomorphically replace silicium ions while the forming pattern charge is compensated by potassium ions, are always present in the tetrahedral layer. The thickness of the pattern is approximately $1 \mathrm{~nm}$. $\mathrm{Mg}^{2+}, \mathrm{Ca}^{2+}, \mathrm{H}_{3} \mathrm{O}^{+}$(hydroxonium) can be present in small numbers in inter-pattern space apart from $\mathrm{K}+$. These cations connect the patterns firmly enough and water polar molecules cannot mix in and cause expanding. Hydromica particles slowly come loose in water. Hydromicas usually go together with other clay materials forming joint mixed-layer structures. Hydromicas are the most popular minerals of clay slate and claystone. $[2,4]$. Correlation relationship between the content of hydromica and calcined potash can be seen. Examinations of targeted fractionated burnt chemicals made it possible to detect kaolinite $-7,13 ; 3,56 ; 2,33 \AA$ and others in most sifting samples.

Crystalline silica being terrigenous addition is detected in all samples. Its diffractive peaks $(3,34 ; 1,82 ; 1,54 ; 4,25 ; 2,45 ; 2,28 ; 2,12 \AA)$ have great intensity due to the high crystallinity. Feldspars and plagioclases (orthoclase feldspars, soda feldspar, anorthite 3,$20 ; 4,04 ; 2,96 ; 2,51 \AA$.) are also seen in almost all samples.

The peaks of chlorite, clinochlore, sheridanite $(7,12 ; 3,53 ; 14,5 ; 4,68 \AA$ and others) can be noticed in almost every X-ray pattern. Chlorite is a mica-like mineral made from alternating maca- and brucite-like layers. Chlorite doesn't usually expand in water because of some specific characteristics of the connection inside and between the patterns. They are always present in the mixture with other clay minerals. Chlorites are identical to illite clay minerals in the size of grains. Chlorite doesn't have a permanent chemical composition therefore there are different kinds of chlorite that have their own names. 


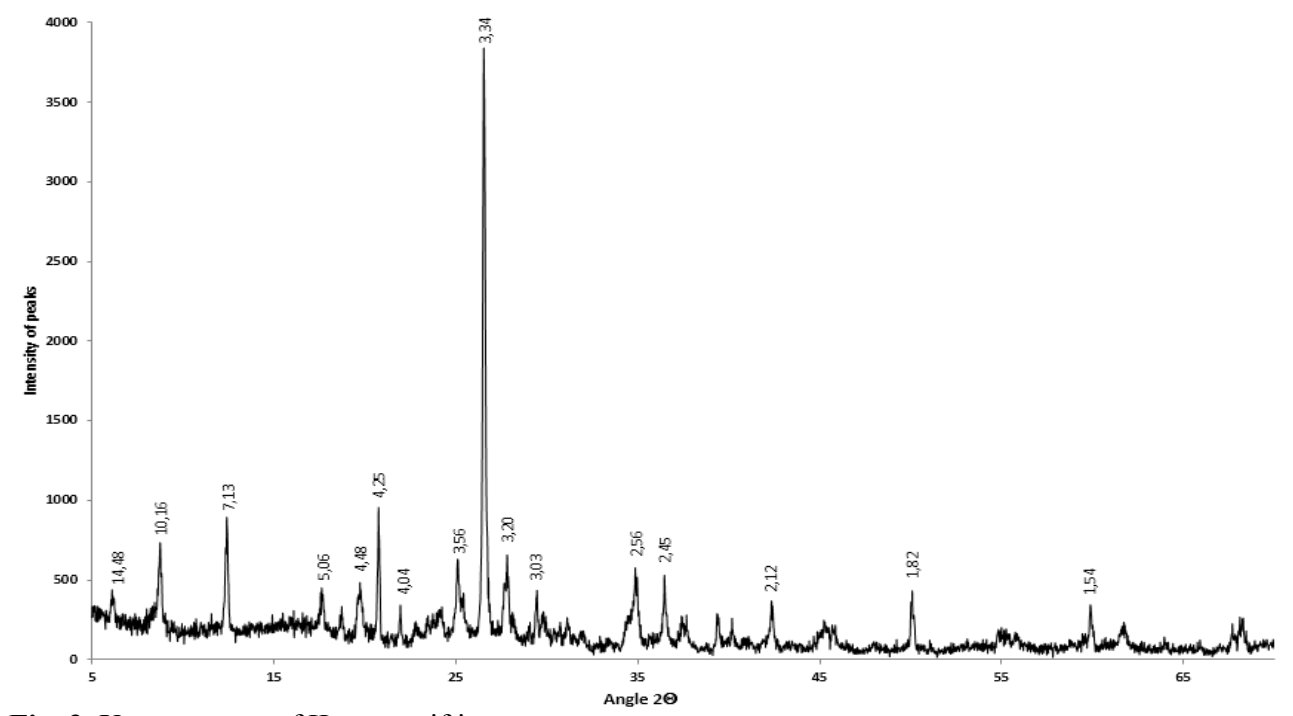

Fig. 3. X-ray pattern of II group siftings

Carried out researches have shown that siftings' preparation as raw material for manufacturing building ceramics consists of their breaking up till the fraction $0-0,63-0$ $0,16 \mathrm{~mm}$. The most suitable equipment for this is pendular mills. At this, grain composition can be characterized by both ongoing and broken grain composition. The more original raw material is crushed, the firmer are the fired products [5-7]. In figure 4, as an example, you can see dependencies of strength and water absorption of fired samples on the burning temperature and the degree of original raw material crushing. As it can be seen from the graphs, at a firing temperature of $1000{ }^{\circ} \mathrm{C}$ and higher, high strength rates can be reached at a rather low water absorption of the samples.

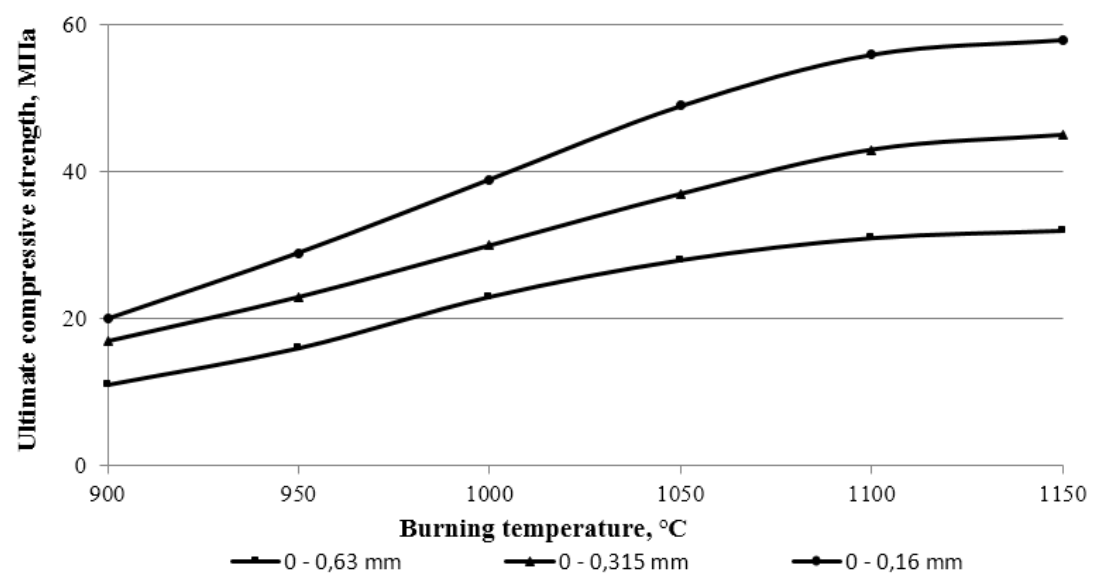

Fig. 4. Influence of fraction rate and burning temperature on the break-down point under compression 


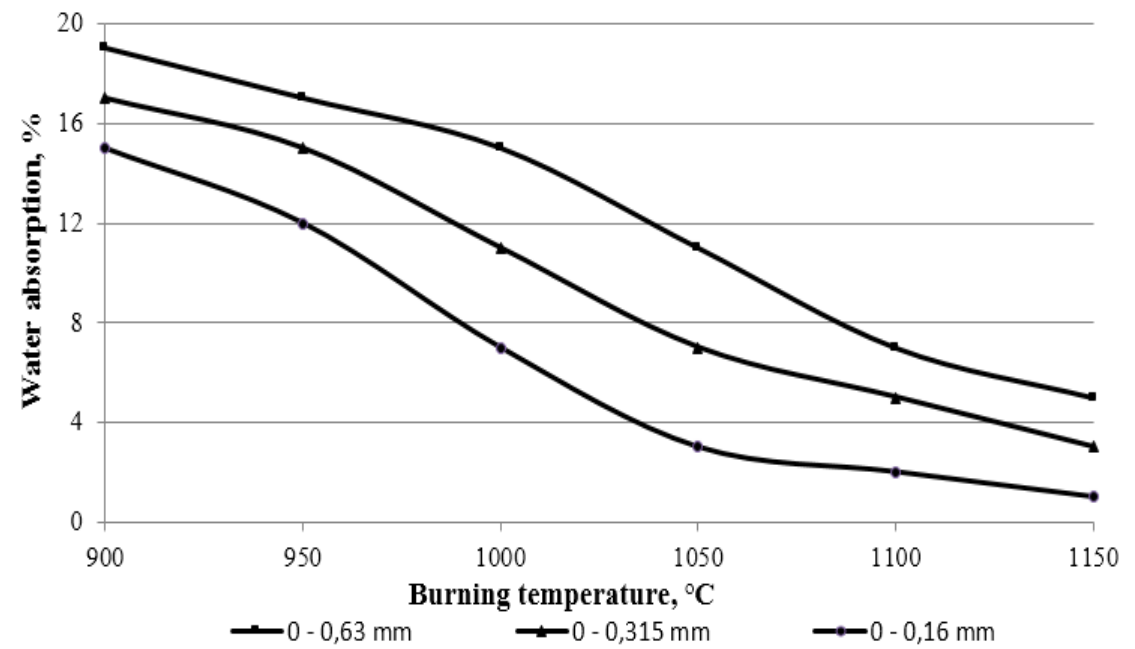

Fig. 5. Influence of fraction rate and burning temperature on water absorption of the samples

The most practical way of producing goods is compression molding at lowered mixing water content and high compression pressure. Method of rough (semirough) extrusion molding with direct product setting on furnace cars can be applied for siftings of the first group. It is possible to get products with a wide range of qualities at varying technology factors. $[8,9]$.

Carried out researches have shown that siftings from gob pile processing are perspective raw material for producing different kinds of wall ceramics goods. Injection of finedispersed particles from the processing of refuse piles containing coal and having paste forming properties into the raw material will give an opportunity to drastically reduce the expenditures for burning and consequently the initial cost of products [6]. Thus application of Eastern Donbass refuse heap siftings in the production of wall ceramics is technically and economically feasible.

\section{References}

1. A.Yu. Stolboushkin, G.I. Storozhenko, Stroitel'nye materialy 4, 43 (2011)

2. B.V. Talpa, A.V. Kotlyar, Stroitel'nye materialy 4, 31 (2015)

3. B. K. Kara-Sal, V.I. Kotelnikov, T.V. Sapelkina, Natural and technical Sciences 2, 160 (2015)

4. V.D. Kotlyar, A.V. Kozlov, A.V. Kotlyar, Yu.V. Terekhina, Vestnik MGSU 10, 95 (2014)

5. A.Yu. Stolboushkin, A.I. Ivanov, V.A. Syropyatov, O.A. Fomina, M.S. Druzhinin, V.I., News universities. Construction 10 (682), 39 (2015)

6. V.D. Kotlyar, K.S. Yavruyan, Stroitel'nye materialy $\underline{4}$, 38 (2017)

7. K. S. Yavruyan, V.D. Kotlyar, E.O. Lotoshnikova, S.E. Gaishun, Stroitel'nye materialy 4, 17 (2018)

8. K.S. Yavruyan, E.S. Gaishun, A.V. Kotlyar, Stroitel'nye materialy 12, 14 (2017) 